\title{
Helminth fauna of Leptodactylus syphax (Anura: Leptodactylidae) from Caatinga biome, northeastern Brazil
}

Helmintofauna de Leptodactylus syphax (Anura: Leptodactylidae) do bioma da Caatinga, Nordeste do Brasil

Aline Gouveia de Souza Lins ${ }^{1 *}$; Aline Aguiarr'; Drausio Honorio Morais²; Lidiane Aparecida Firmino da Silva'; Robson Waldemar Ávila²; Reinaldo José da Silva ${ }^{1}$

\author{
${ }^{1}$ Departamento de Parasitologia, Instituto de Biociências, Universidade Estadual Paulista - UNESP, Botucatu, SP, Brasil \\ ${ }^{2}$ Programa de Pós-gradução em Bioprospecção Molecular, Universidade Regional do Cariri - URCA, Campus do Pimenta, Crato, \\ CE, Brasil
}

Received November 30, 2016

Accepted February 21, 2017

\begin{abstract}
Leptodactylus syphax is distributed in central, southeastern and northeastern Brazil, eastern Bolivia and southern Paraguay, occupying open areas and rock outcrops, in rock cavities and termite burrows. We collected 21 frogs from the Caatinga region of the state of Ceará, northeastern Brazil, and 7,021 helminths were recovered from 18 of these hosts (overall prevalence $=85.7 \%)$. Six helminth taxa were recovered, as follows: Aplectana membranosa $(\mathrm{n}=3,756)$; Schrankiana formosula $(\mathrm{n}=3,176)$; larvae of Physaloptera sp. $(\mathrm{n}=43)$; unidentified nematode larvae $(\mathrm{n}=7)$; digenean metacercariae of Lophosicyadiplostomum sp. $(\mathrm{n}=2)$; and cystacanths of Acanthocephala $(\mathrm{n}=37)$. The similarity of helminth composition between L. syphax from the Caatinga and other species of the L. fuscus group showed that some anurans were clustered according to parasite species and others according to geographic locality. This study presents new helminth records for the Neotropical region, thus helping in understanding the pattern of species distribution, and it increases the knowledge of parasites associated with amphibians.
\end{abstract}

Keywords: Leptodactylus fuscus group, helminths, parasites, L. syphax, Caatinga.

\section{Resumo}

Leptodactylus syphax está distribuída na região central, Sudeste e Nordeste do Brasil, Leste da Bolívia e Sul do Paraguai, ocupando áreas abertas e afloramentos rochosos, cavidades rochosas ou de cupins. Foram coletadas 21 rãs oriundas da região de Caatinga do Ceará, nordeste brasileiro, e 7.021 helmintos foram recuperados em 18 hospedeiros (prevalência geral $=85,7 \%)$. Seis taxa de helmintos foram recuperados, como segue: Aplectana membranosa $(\mathrm{n}=3.756)$, Schrankiana formosula $(\mathrm{n}=3.176)$, larvas de Physaloptera sp. $(\mathrm{n}=43)$, larvas de nematódeos náo identificado $(\mathrm{n}=7)$, metacercárias de Lophosicyadiplostomum sp. $(\mathrm{n}=2)$, e cistacantos de Acantocéfalos $(\mathrm{n}=37)$. A similaridade da composição de helmintos entre L. syphax da Caatinga e outras espécies do grupo L. fuscus mostrou que alguns anuros foram agrupados de acordo com a espécie do parasita e outros de acordo com a localidade geográfica. Este estudo apresenta novos registros de helmintos para a região Neotropical, ajudando na compreensão do padrão de distribuição das espécies e aumenta o conhecimento sobre os parasitas associados a anfíbios.

Palavras-chave: Leptodactylus fuscus grupo, helmintos, parasitas, L. syphax, Caatinga.

\section{Introduction}

Knowledge about biological diversity and its distribution is of such importance that it should be considered before any further study. Global diversity includes parasites such as helminths, which

*Corresponding author: Aline Gouveia de Souza Lins. Departmento de Parasitologia, Instituto de Biociências, Universidade Estadual Paulista - UNESP, Av. Bento Lopes, s/n, CP 510, Distrito de Rubião Júnior, CEP 18618-970, Botucatu, SP, Brasil. e-mail: alinegouveia51@hotmail.com are associated with several vertebrates and can be modulated by their host and environment. Helminths can also influence host population conditions through co-evolutionary processes (POULIN, 1995, 1999). Compared with what is known about the helminth fauna of some vertebrates, such as fish, birds and mammals, knowledge of helminth richness in amphibians is relatively poor (AHO, 1990). Considering the richness of anuran species in Brazil - around 1026 species (SEGALLA et al., 2014; FROST, 
2015) - the number of helminth species is expected to be higher. In the Caatinga biome, located in northeastern Brazil, there are approximately 53 anuran species, and most of them have an unknown helminth fauna (ALBUQUERQUE et al., 2012; CAMPIÃO et al., 2014). One of these species is Leptodactylus syphax (Bokermann, 1969), which is distributed across central, southeastern and northeastern Brazil, eastern Bolivia and southern Paraguay, occupying open areas and rocky outcrops, in rock or termite cavities. This species does not seem to adapt well to anthropogenic disturbance (IUCN, 2015).

According to De Sá et al. (2014), the leptodactylid species Leptodactylus syphax was placed in the Leptodactylus fuscus group, which is composed of species of similar sizes that occupy similar niches and are phylogenetically close together. On the other hand, the species of this group have wide distribution and occupy different habitats, which can influence component communities of related parasites (GOATER \& GOATER, 2001). However, there is only one record of a helminth parasite associated with L. syphax: the nematode Aplectana sp., which was reported from the state of Mato Grosso do Sul, Brazil (CAMPIÃO et al., 2014).

In the present study, the component community of helminths associated with L. syphax in the Caatinga, Brazil, is reported. In addition, the similarity of helminth community composition in other species of the L. fuscus group from different South American regions is compared in order to analyze whether clusters were formed according to geographic region or helminth species.

\section{Materials and Methods}

This study was conducted in the municipality of Farias Brito, Cariri region, state of Ceará, northeastern Brazil. Twenty-one specimens of $L$. syphax were collected through visual encounter surveys from February 2013 to August 2014, fixed in 10\% formalin, preserved in 70\% alcohol and then deposited in the Herpetological Collection of the Regional University of Cariri, (URCA-H 4864, 4865, 4866, 4867, 4868, 4876, 4882, 4923, 4924, 4925, 4926, 4929, 4933, 4936, 4938, 7144, 7145, 7149, $7152,9823,9949)$, municipality of Crato, state of Ceará. All organs were removed and examined individually under a stereoscope and the helminths collected were transferred to $70 \%$ ethanol. Larvae of Acanthocephala (cystacanths) and metacercariae were stained with alcoholic hydrochloric acid-carmine and cleared in creosote, while nematodes were diaphanized in lactophenol. Helminths were deposited in the Coleção Helmintológica do Instituto de Biociências de Botucatu (CHIBB 7956, 7957, 7958, 7959, 7960, 7961, 7962, 7963, 7964, 7965, 7966, 7967, 7968, 7969, 7970, 7971, 7972, 7973, 7974, 7975, $7976,7977,7978)$. Subsequently, these temporary slides were analyzed using a microscope equipped with the LASV3.8 image system. The collection of specimens of $L$. syphax was authorized by SISBIO (\#32758-2).

As described by Bush et al. (1997), we used ecological descriptors such as prevalence, mean abundance and mean intensity of infection. These descriptors were calculated in the SigmaStat 3.1 software (SYSTAT Software, Inc.). The similarity of the helminth fauna of the L. fuscus species group in which L. syphax is included was analyzed considering the geographic localities occupied by these species, and a cluster analysis was performed using the Bray-Curtis similarity index performed using the Past software (BRAY \& CURTIS, 1957), scored as presence (1) or absence (0) of data on helminth species.

\section{Results}

\section{Helminths associated with Leptodactylus syphax from the Caatinga}

We recovered 7,021 helminths from 18 of the 21 specimens of L. syphax, thus resulting in overall prevalence of $85.7 \%$, mean abundance of $334.3 \pm 85.0$ and an average of $390.0 \pm 93.0$ helminths in each infected host, with parasitism intensity ranging from at least two up to 1,300 helminths. The mean richness was $1.4 \pm 0.2$ species and the taxon richness in the component community comprised four nematode species: Aplectana membranosa ( $\mathrm{n}=3756)$; Schrankiana formosula ( $\mathrm{n}=3176)$; larvae of Physaloptera sp. $(\mathrm{n}=43)$; unidentified larvae $(\mathrm{n}=7)$; digenean metacercariae of Lophosicyadiplostomum sp. $(\mathrm{n}=2)$; and cystacanths of Acanthocephala $(\mathrm{n}=37)$ (Table 1).

Table 1. Prevalence (P\%), mean intensity of infection (MII), mean abundance (MA) with standard error (SE), range of infection (Ri) and site of infection (SI) of helminths associated with Leptodactylus syphax from the Caatinga, Brazil.

\begin{tabular}{|c|c|c|c|c|c|}
\hline Helminthes & $\mathbf{P} \%$ & MII & $\mathbf{R i}$ & MA & SI* \\
\hline \multicolumn{6}{|l|}{ Nematoda } \\
\hline Aplectana membranosa & 71.4 & $250.4 \pm 63.0$ & $2-771$ & $178.8 \pm 51.2$ & $\mathrm{Si}, \mathrm{Li}$ \\
\hline Schrankiana formosula & 42.9 & $353.0 \pm 128.1$ & $6-1000$ & $151.2 \pm 65.9$ & $\mathrm{Li}$ \\
\hline Physaloptera sp. (larvae) & 9.5 & $21.5 \pm 19.5$ & $2-41$ & $2.0 \pm 1.9$ & Sto \\
\hline Unidentified larvae & 4.8 & 7.0 & - & $0.3 \pm 0.3$ & Cav \\
\hline \multicolumn{6}{|l|}{ Digenea } \\
\hline Lophosicyadiplostomum sp. (metacercariae) & 4.8 & 2.0 & 2 & $0.1 \pm 0.1$ & Kid \\
\hline \multicolumn{6}{|l|}{ Acanthocephala } \\
\hline Cystacanths & 4.7 & 37.0 & 37 & $1.7 \pm 1.7$ & Cav \\
\hline Total & 85.7 & $390.0 \pm 93.0$ & $2-1300$ & $334.3 \pm 85.0$ & - \\
\hline
\end{tabular}

${ }^{*} \mathrm{Si}$ (small intestine), Li (large intestine), Sto (stomach), Cav (body cavity), and Kid (kidneys). 
Similarity to helminth community composition of other species of the Leptodactylus fuscus group in different South American regions

Only eight species in the $L$. fuscus group have helminth records from South American countries, in Argentina, Brazil, Ecuador, Paraguay and Peru (Table 2). Among these, Argentina and Brazil have provided most of the records. Based on these records, a cluster with a cophenetic correlation coefficient of 0.81 was presented (Figure 1). Some hosts were grouped according to locality and others according to the composition of helminth species. Hosts sampled in the state of Mato Grosso do Sul (MS) shared the same clade of helminth species with similarity (0.6) shown in a cluster for L. elenae and L. syphax (1.0), with closer similarity than between L. fuscus and L. mystacinus (0.8). Another pair of hosts that showed a correlation was L. bufonius and L. mystacinus (0.6): although from different localities, both shared Oswaldocruzia proencai with L. bufonius from Paraguay (0.4). Leptodactylus fuscus and L. mystaceus showed similarity (0.6) from Rio de Janeiro. Leptodactylus fuscus and L. mystacinus; and L. fuscus and L. mystaceus, from different localities, presented the same similarity measurement (0.5). Leptodactylus syphax from Ceará was more similar to L. mystacinus from Rio de Janeiro (0.2) Three host species formed an outgroup because they did not share any helminth species $(0.0)$.

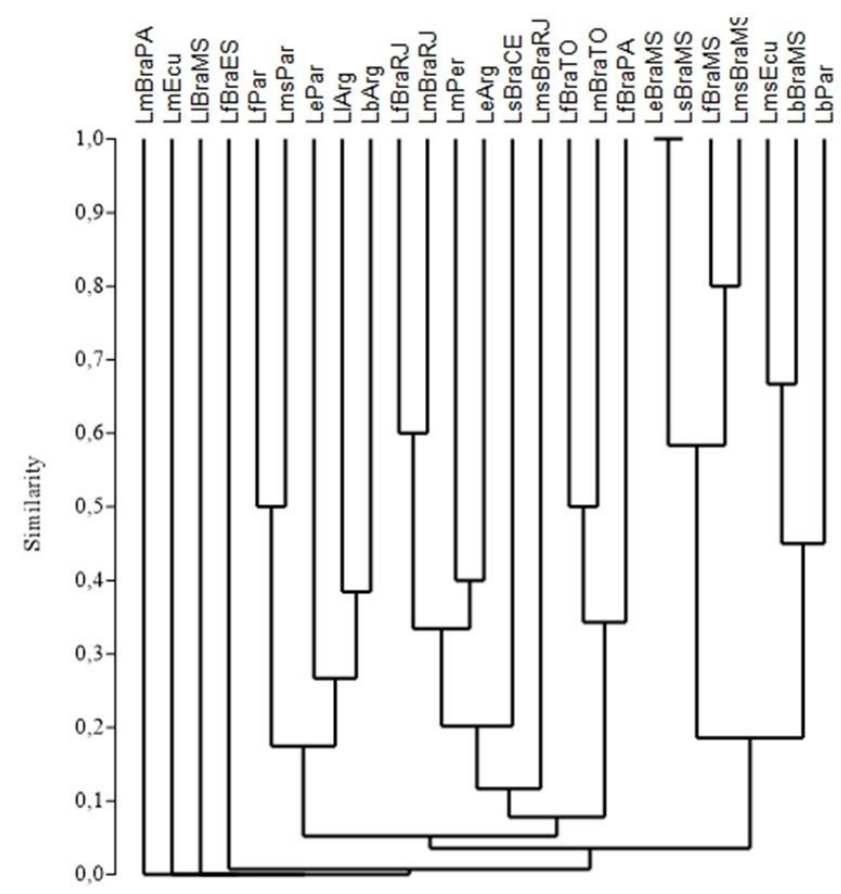

Figure 1. Cluster analysis based on the composition of helminth parasites of the Leptodactylus fuscus group from South America. Host species: Leptodactylus bufonius (Lb), Leptodactylus elenae (Le), Leptodactylus fuscus (Lf), Leptodactylus latinasus (Ll), Leptodactylus mystaceus (Lm), Leptodactylus mystacinus (Lms) and Leptodactylus syphax (Ls). Original records: Argentina (Arg), Brazil (Bra), Ecuador (Ecu), Paraguay (Par) and Peru (Per). Brazilian States: Ceará (CE), Espírito Santo (ES), Mato Grosso do Sul (MS), Pará (PA), Rio de Janeiro (RJ) and Tocantins (TO).

\section{Discussion}

Although members of Leptodactylidae have been included in many studies on helminth fauna in relation to other families, the present study shows the helminth component community of L. syphax for the first time. In addition, this is the first study conducted on this host in the Brazilian Caatinga. Also, this is the first record of Lophosicyadiplostomum sp. for all anurans of the family Leptodactylidae and the first record of parasitism by all these helminths in hosts in the Caatinga, which extends their geographic distribution, except for Aplectana sp., Physaloptera larvae and Acanthocephala, which had already been recorded in Rhinella jimi and $R$. granulosa in the Caatinga biome (MADELAIRE, 2012).

The parasite community of L. syphax showed low richness, compared with the congeneric group. The environment conditions found in the Caatinga, which is characterized by long periods of drought, may have had an influence, through not allowing other forms of infection to become established (e.g. indirect-cycle parasites). Community richness would vary depending on the environmental conditions because of the way in which species respond to biotic factors (POULIN \& KRASNOV, 2010).

The component community of helminths in L. syphax in this study comprised four species of Nematoda, one of Acanthocephala and one of Digenea, while Vicente et al. (1990) recorded Aplectana sp., which is a very common nematode in the intestines of frogs of the Leptodactylidae group (Table 2), and Schrankiana formosula, another nematode that is found only in the large intestine, as well as in L. fuscus (GOLDBERG et al., 2007). These two nematode species presented the highest prevalence, mean abundance and mean intensity of infection, which can be explained by the greater host body surface, which means they are more exposed to infective stages of parasites (POULIN, 1995). In addition to this, these nematode species of the family Cosmocercidae and Atractidae have direct life cycles and, in the case of $A$. membranosa, the females produce great quantities of eggs, thus resulting in higher reproductive rates and higher abundance of infective larvae in the environment, while $S$. formosula, according Anderson (2000) who claims that family Atractidae presents autoinfective species. There is a passive interaction between these two species, relating to limited resources and to the fact that both of them need to exploit their host in a very short time (DE JONG, 1976; IVES \& MAY, 1985; LOMNICKI, 1988), referring to the reproductive mode of Cosmocercidae.

Larvae of Physaloptera sp. were recovered from the stomach of L. syphax, which can be considered to be an intermediate or paratenic host for this helminth because its diet consists mostly of insects, which harbor the infective larvae (OLSEN, 1986). Species of the L. fuscus group show ecological similarities, in that they live temporarily near puddles while at the tadpole stage, but in the adult stage they remain in terrestrial environments and receive further infection by nematodes through oral ingestion or penetration through the skin, in spite of their body length and different localities. Thus, these nematodes are characterized as having low specificity (ANDERSON, 2000).

The presence of cystacanths in cavities suggests that L. syphax can be considered to be an intermediate or paratenic host, such 
Table 2. Records of helminths associated with leptodactylids of the Leptodactylus fuscus group in South American countries, according to Campião et al. (2014). TR (Transchaco), CO (Province of Corrientes), MS (State of Mato Grosso do Sul), AS (Assunción), CH (Chaco), RC (Province of Remanso Castillo), CN (Province of Concepción), SM (Province of Santa Maria), PA (State of Pará), ES (State of Espiríto Santo), RJ (State of Rio de Janeiro), TO (State of Tocantins), SCE (Province of Santa Cecilia) and CU (Cuzco).

\begin{tabular}{|c|c|c|c|c|}
\hline Host & Parasite & Country & Locality & Reference \\
\hline \multirow{23}{*}{ Leptodactylus bufonius } & Acanthocephalus caspanensis & Paraguay & $\mathrm{TR}$ & Smales (2007) \\
\hline & Centrorhynchus sp. & Argentina & $\mathrm{CO}$ & González \& Hamann (2006) \\
\hline & Ortleppascaris sp. & Argentina & $\mathrm{CO}$ & González \& Hamann (2006) \\
\hline & Aplectana hylambatis & Argentina & $\mathrm{CO}$ & González \& Hamann (2006) \\
\hline & Aplectana sp. & Argentina & $\mathrm{CO}$ & González \& Hamann (2006) \\
\hline & Cosmocerca ornata & Brazil & not reported & Baker \& Vaucher (1984) \\
\hline & Cosmocerca parva & Argentina & $\mathrm{CO}$ & González \& Hamann (2006) \\
\hline & Cosmocerca podicipinus & Argentina & $\mathrm{CO}$ & González \& Hamann (2006) \\
\hline & Physaloptera sp. & Argentina & $\mathrm{CO}$ & González \& Hamann (2006) \\
\hline & Oswaldocruzia proencai & Brazil & MS & Vicente et al. (1990) \\
\hline & & Paraguay & AS & Lent et al. (1946) \\
\hline & & Argentina & $\mathrm{CH}$ & Lent et al. (1946) \\
\hline & & Paraguay & $\mathrm{RC}$ & Lent et al. (1946) \\
\hline & Oswaldocruzia sp. & Argentina & $\mathrm{CO}$ & González \& Hamann (2006) \\
\hline & Rhabdias elegans & Argentina & $\mathrm{CO}$ & González \& Hamann (2006) \\
\hline & Schulzia travassosi & Paraguay & $\mathrm{CN}$ & Durette-Desset et al. (1986) \\
\hline & & Argentina & not reported & González \& Hamann (2015) \\
\hline & Catadiscus inopinatus & Argentina & $\mathrm{CO}$ & Hamann, et al. (2006) \\
\hline & Glypthelmins repandum & Argentina & $\mathrm{CO}$ & González \& Hamann (2006) \\
\hline & Aplectana delirae & Argentina & $\mathrm{CO}$ & González \& Hamann (2016) \\
\hline & Aplectana elenae & Paraguay & not reported & Baker (1987) \\
\hline & Aplectana hylambatis & Paraguay & not reported & Baker \& Vaucher (1986) \\
\hline & Aplectana paraelenae & Paraguay & not reported & Baker (1987) \\
\hline \multirow[t]{13}{*}{ Leptodactylus elenae } & Aplectana sp. & Brazil & MS & Baker \& Vaucher (1986) \\
\hline & Cosmocerca podicipinus & Paraguay & not reported & Baker \& Vaucher (1986) \\
\hline & Cosmocerca parva & Argentina & $\mathrm{CO}$ & González \& Hamann (2016) \\
\hline & Oxyascaris oxyascaris & Paraguay & not reported & Baker \& Vaucher (1986) \\
\hline & Schrankiana formosula & Paraguay & not reported & Baker \& Vaucher (1988) \\
\hline & Oswaldocruzia proencai & & not reported & Vicente et al. (1990) \\
\hline & Schrankiana formosula & Brazil & PA & Goldberg et al. (2007) \\
\hline & & Brazil & RJ & Freitas, 1959 apud Campião et al. (2014) \\
\hline & Schrankiana fuscus & Brazil & PA & Goldberg et al. (2007) \\
\hline & Schrankiana larvata & Brazil & PA & Goldberg et al. (2007) \\
\hline & & Brazil & $\mathrm{TO}$ & Freitas, 1959 apud Campião et al. (2014) \\
\hline & & Brazil & MS & Freitas, 1959 apud Campião et al. (2014) \\
\hline & Aplectana hylambatis & Paraguay & not reported & Baker \& Vaucher (1986) \\
\hline \multirow{10}{*}{ Leptodactylus fuscus } & Aplectana sp. & Brazil & MS & Freitas, 1959 apud Campião et al. (2014) \\
\hline & Cosmocerca parva & Brazil & RJ & Vicente et al. (1990) \\
\hline & Cosmocerca podicipinus & Brazil & $\mathrm{TO}$ & Baker \& Vaucher (1986) \\
\hline & Oxyascaris oxyascaris & Brazil & MS & Baker \& Vaucher (1986) \\
\hline & Oxyascaris caudacutus & Brazil & RJ & Vicente et al. (1990) \\
\hline & Ochoterenella convoluta & Brazil & not reported & Walton (1935) \\
\hline & Oswaldocruzia mazzai & Brazil & TO & Goldberg et al. (2009) \\
\hline & Oswaldocruzia vaucheri & Brazil & PA & Goldberg et al. (2007) \\
\hline & Oswaldocruzia sp. & Brazil & ES & Travassos et al., 1964 apud Campião et al. (2014) \\
\hline & Mesocoelium monas & Brazil & RJ & Rodrigues et al. (1990) \\
\hline Leptodactylus gracilis & Strongyloides carinii & Brazil & not reported & Pereira, 1935 apud Campião et al. (2014) \\
\hline
\end{tabular}


Table 2. Continued...

\begin{tabular}{|c|c|c|c|c|}
\hline Host & Parasite & Country & Locality & Reference \\
\hline \multirow{14}{*}{ Leptodactylus latinasus } & Schrankiana schranki & Argentina & $\mathrm{CO}$ & Hamann et al. (2006) \\
\hline & Aplectana hylambatis & Argentina & $\mathrm{CO}$ & Hamann et al. (2006) \\
\hline & Cosmocerca cruzi & Argentina & $\mathrm{CO}$ & Hamann et al. (2006) \\
\hline & Cosmocerca parva & Argentina & $\mathrm{CO}$ & Hamann et al. (2006) \\
\hline & Cosmocerca podicipinus & Argentina & $\mathrm{CO}$ & Hamann et al. (2006) \\
\hline & Cosmocerca rara & Argentina & $\mathrm{CO}$ & Hamann et al. (2006) \\
\hline & Bursotrema aff.tetracotyloides & Argentina & $\mathrm{CO}$ & Hamann et al. (2006) \\
\hline & Catadiscus inopinatus & Argentina & $\mathrm{CO}$ & Hamann et al. (2006) \\
\hline & Petasiger sp. & Argentina & $\mathrm{CO}$ & Hamann et al. (2006) \\
\hline & Styphlodora sp. & Argentina & $\mathrm{CO}$ & Hamann et al. (2006) \\
\hline & Travtrema aff. stenocotyle & Argentina & $\mathrm{CO}$ & Hamann et al. (2006) \\
\hline & Glypthelmins repandum & Argentina & $\mathrm{CO}$ & Hamann et al. (2006) \\
\hline & Haematoloechus longiplexus & Argentina & $\mathrm{CO}$ & Hamann et al. (2006) \\
\hline & Opisthogonimus sp. & Argentina & $\mathrm{CO}$ & Hamann et al. (2006) \\
\hline \multirow{14}{*}{ Leptodactylus mystaceus } & Aplectana membranosa & Brazil & RJ & Rodrigues (1986) \\
\hline & Aplectana travassosi & Ecuador & SCE & Dyer (1990) \\
\hline & Cosmocerca parva & Brazil & RJ & Fabio, 1982 apud Campião et al. (2014) \\
\hline & & Peru & $\mathrm{CU}$ & Bursey et al. (2001) \\
\hline & Mesocoelium monas & Brazil & RJ & Fabio, 1982 apud Campião et al. (2014) \\
\hline & Oxyascaris caudacutus & Brazil & RJ & Fabio, 1982 apud Campião et al. (2014) \\
\hline & Oxyascaris oxyascaris & Brazil & RJ & Fabio, 1982 apud Campião et al. (2014) \\
\hline & Oswaldocruzia proencai & Ecuador & SCE & Dyer \& Altig (1977) \\
\hline & Physaloptera sp. & Brazil & RJ & Fabio, 1982 apud Campião et al. (2014) \\
\hline & & Peru & $\mathrm{CU}$ & Bursey et al. (2001) \\
\hline & Physalopteroides venancioi & Peru & $\mathrm{CU}$ & Bursey et al. (2001) \\
\hline & Schrankiana freitasi & Brazil & PA & Goldberg et al. (2007) \\
\hline & Schrankiana larvata & Brazil & $\mathrm{TO}$ & Goldberg et al. (2009) \\
\hline & & Peru & $\mathrm{CU}$ & Bursey et al. (2001) \\
\hline \multirow{7}{*}{ Leptodactylus mystacinus } & Centrorhynchus sp. & Brazil & RJ & Fabio, 1982 apud Campião et al. (2014) \\
\hline & Aplectana hylambatis & Paraguay & not reported & Baker \& Vaucher (1986) \\
\hline & Aplectana macintoshii & Paraguay & not reported & Baker \& Vaucher (1986) \\
\hline & Aplectana sp. & Brazil & MS & Travassos, 1925 apud Campião et al. (2014) \\
\hline & Cosmocerca ornata & Paraguay & not reported & Baker \& Vaucher (1986) \\
\hline & Oxyascaris oxyascaris & Brazil & MS & Travassos, 1925 apud Campião et al. (2014) \\
\hline & Mesocoelium monas & Brazil & RJ & Freitas, 1967 apud Campião et al. (2014) \\
\hline Leptodactylus syphax & Aplectana sp. & Brazil & MS & Vicente et al. (1990) \\
\hline
\end{tabular}

that this helminth was acquired through ingestion of arthropods. Some species of Acanthocephala are found in amphibians: in most cases, the cystacanths adhered to the mesentery for transportation by an anuran from an aquatic intermediary host to an aquatic predatory bird, for example (KENNEDY, 2006).

Metacercariae of Lophosicyadiplostomum were reported for the first time in a frog of the family Leptodactylidae, in the present study. They were found in the kidneys, thus corroborating previous studies in which this digenean was reported in cyst form at this same infection site. Many digeneans parasitize amphibians: for example, the L. fuscus group includes L. latinasus (HAMANN et al., 2006), which has been reported to be infected by both aquatic and terrestrial parasites. Metacercariae of Lophosicyadiplostomum aff. nephrocystis were found in the kidneys of Scinax nasicus, (HAMANN
\& GONZÁLEZ, 2009), Hyla nana and Lysapsus limellum (HAMANN \& KEHR, 1998, 1999). Infection with this trematode may have occurred by penetration of cercariae beyond the host's cloaca, subsequently reaching the kidneys. On the other hand, considering the life cycle of Diplostomidae, gastropods could be ingested by anurans and then the larvae could reach anurans' kidneys as reported by Gonzalez \& Hamann (2006).

Most hosts within the L. fuscus group have shown similarity regarding the areas sampled, but some species have been grouped according to helminth species that they share (Figure 1). The helminth fauna of L. syphax in the Caatinga was most similar to that of L. mystaceus and L. fuscus, in different regions, because they shared three nematode species. Nematodes generally do not have a specificity pattern, and therefore the ability of parasites to 
explore a wider range of hosts results in better use of resources and opportunities for successful biological cycles (POULIN, 2005). The host species in question belong to the same group and do not differ much regarding ecology and physiology, although the sampling points for each host have had very different characteristics, even involving different biomes (e.g. Caatinga, Atlantic Forest, high altitude as in Cuzco, or the Chaco region of Argentina).

Diverse mechanisms for host infection, the low level of general environmental requirements for these helminths and low host specificity allow parasite infection even in completely different environments (SOUSA \& GROSHOLZ, 1991). Specimens of L. syphax collected from the Caatinga presented a fauna mostly composed of nematodes considering the number of parasites, that were in most cases, parasites with a direct life cycle (ANDERSON, 2000) that did not require intermediate host. The requirement for an intermediate host usually occurs in environments with greater abundance of water. The Caatinga has extremely low rainfall, with a very long dry season (DUELLMAN, 1999), and consequently there are few environments available for parasites with an indirect life cycle, as opposed to environments from which congeneric species were collected. In addition, $L$. syphax presents a terrestrial habit and active forager, which favors infection by direct life cycle parasites, once this host remains most of its life in the soil.

Knowledge of the helminth fauna associated with vertebrates improves the data on biodiversity and increases the records of occurrences of species of parasites and their relationships with their hosts. This helps expand knowledge of the distribution patterns of these species and aids future studies on ecological host-parasite relationships.

\section{Acknowledgements}

Financial support for this study was provided by the Research Support Foundation of the State of São Paulo (Fundação de Amparo a Pesquisa do Estado de São Paulo, FAPESP) (grant no. 2012/24945-1). Robson Waldemar Ávila thanks the National Council for Scientific and Technological Development (Conselho Nacional de Desenvolvimento Científico e Tecnológico, CNPq) for providing a research fellowship (no. 303622/2015-6) and Drausio H. Morais thanks the Coordination Office for Improvement of Higher Education Personnel (Coordenação de Aperfeiçoamento de Pessoal de Nível Superior, CAPES) for providing a research fellowship (CAPES/PNPD no. 22005013001P4).

\section{References}

Aho JM. Helminth communities of amphibians and reptiles: comparative approaches to understanding patterns and processes. In: Esch GW, Bush AO, Aho JM. Parasite communities: patterns and process. London: Chapman \& Hall; 1990. p. 157-195.

Albuquerque UP, Araújo EL, El-Deir ACA, Lima ALA, Souto A, Bezerra BM, et al. Caatinga Revisited: Ecology and Conservation of an Important Seasonal Dry Forest. Sci World J 2012; 2012: 1-18. PMid:22919296. http://dx.doi.org/10.1100/2012/205182.

Anderson RC. Nematode parasites of vertebrates: their development and transmission. 2nd ed. New York: CABI Publishing; 2000.
Baker MR. Synopsis of the Nematoda parasitic in amphibians and reptiles. 11st ed. Newfoundland: Memorial University; 1987. p. 325. Occasional Papers in Biology.

Baker MR, Vaucher C. Parasitic helminths from Paraguay VI: Cosmocerca Diesing, 1861 (Nematoda: Cosmocercoidea) from frogs. Rev Suisse Zool 1984; 91: 925-934. http://dx.doi.org/10.5962/bhl.part.81589.

Baker MR, Vaucher C. Parasitic helminths from Paraguay XII: Aplectana Raillet \& Henry, 1916 (Nematoda: Cosmocercoidea) from frogs. Rev Suisse Zool 1986; 93: 607-616. http://dx.doi.org/10.5962/bhl.part.79500.

Baker MR, Vaucher C. Parasitic helminths from Paraguay XV: Atractidae (Nematoda: Cosmocercoidea) from frogs. Rev Suisse Zool 1988; 95: 421431. http://dx.doi.org/10.5962/bhl.part.79661.

Bray JR, Curtis JT. An ordination of upland forest communities of southern Wisconsin. Ecol Monogr 1957; 27(4): 325-349. http://dx.doi. org/10.2307/1942268.

Bursey CR, Goldberg SR, Parmelee JR. Gastrointestinal helminths of 51 species of anurans from Reserva Cuzco Amazónico, Peru. Comp Parasitol 2001; 68(1): 21-35.

Bush AO, Lafferty KD, Lotz JM, Shostak AW. revisited. J Parasitol 1997; 83(4): 575-583. PMid:9267395. http://dx.doi.org/10.2307/3284227.

Campião KM, Morais DH, Dias OT, Aguiar A, Toledo G, Tavares LER, et al. Checklist of Helminth parasites of Amphibians from South America. Zootaxa 2014; 3843(1): 1-93. PMid:25082165. http://dx.doi. org/10.11646/zootaxa.3843.1.1.

De Jong G. A model of competition for food. I. Frequency-dependent viabilities. Am Nat 1976; 110(976): 1013-1027. http://dx.doi. org/10.1086/283124.

De Sá RO, Grant T, Camargo A, Heyer WR, Ponssa ML, Stanley E. Systematics of the neotropical genus Leptodactylus Fitzinger, 1826 (Anura: Leptodactylidae): Phylogeny, the relevance of non-molecular evidence, and species accounts. South Am J Herpetol 2014; 8(S1): 1-128.

Duellman WE. Distribution patterns of amphibians in South America. In: Duellman WE. Patterns of distribution of amphibians: a global perspectives. Baltimore: The Johns Hopkins University Press; 1999. p. 255-327.

Durette-Desset MC, Baker NR, Vaucher C. Helminthes parasites du Paraguay IX. Remaniement et redefinition du genre Schulzia Travassos, 1937. Rev Suisse Zool 1986; 93(4): 811-821.

Dyer WG. Augmented description of Aplectana travassosi (Nematoda: Cosmocercidae) from Leptodactylid frogs of Ecuador. J Parasitol 1990; 76(5): 639-640. http://dx.doi.org/10.2307/3282974.

Dyer WG, Altig R. Helminths of some ecuadorian anurans. Herpetologica 1977; 33(3): 293-296.

Frost DR. Amphibian species of the world: an online reference. Am Mus Nat Hist [online]. 2015 [cited 2016 July 3]. Available from: http:// research.amnh.org/herpetology/amphibia/index.html

Goater TM, Goater CP. Ecological monitoring and assessment network: protocols for measuring biodiversity: Parasites of amphibians and reptiles [online]. 2001 [cited 2016 July 3]. Available from: http://publications. gc.ca/collections/collection_2014/ec/En14-160-2001-eng.pdf

Goldberg SR, Bursey CR, Caldwell JP, Shepard DB. Gastrointestinal helminths of six sympatric species of Leptodactylus from Tocantins State, Brazil. Comp Parasitol 2009; 76(2): 258-266. http://dx.doi. org/10.1654/4368.1. 
Goldberg SR, Bursey CR, Caldwell JP, Vitt LJ, Costa GC. Gastrointestinal helminths from six species of frogs and three species of lizards, sympatric in Pará state, Brazil. Comp Parasitol 2007; 74(2): 327-342. http://dx.doi. org/10.1654/4268.1.

González CE, Hamann MI. Helmintos parásitos de Leptodactylus bufonius Boulenger, 1894 (Anura: Leptodactylidae) de Corrientes, Argentina. Rev Esp Herpetol 2006; 20: 39-46.

González CE, Hamann MI. First report of Schulzia travassosi (Nematoda, Trichostrongylina, Molineoidea) for amphibians of the Chaco region in Argentina and proposal of Oswaldocruzia melanostictusi nov. comb. Acta Parasitol 2015; 60(4): 784-790. PMid:26408605. http://dx.doi. org/10.1515/ap-2015-0111.

González CE, Hamann MI. Nematode parasites of Leptodactylus elenae and Leptodactylus podicipinus (Anura: Leptodactylidae) from Corrientes, Argentina. Comp Parasitol 2016; 83(1): 117-121. http://dx.doi. org/10.1654/1525-2647-83.1.117.

Hamann MI, González CE. Larval digenetic trematodes in tadpoles of six amphibian species from northeastern Argentina. J Parasitol 2009; 95(3): 623-628. PMid:19045934. http://dx.doi.org/10.1645/GE-1738.1.

Hamann MI, González CE, Kehr AI. Helminth community structure of the oven frog Leptodactylus latinasus (Anura: Leptodactylidae) from Corrientes, Argentina. Acta Parasitol 2006; 51(4): 294-299. http://dx.doi. org/10.2478/s11686-006-0045-1.

Hamann MI, Kehr AI. Variación espacio temporal en infrapoblaciones de helmintos y su relación con las fluctuaciones poblacionales de Hyla nana (Anura, Hylidae). Cuad Herp 1998; 12(2): 23-33.

Hamann MI, Kehr AI. Relaciones ecologicas entre metacercarias de Lophosicyadiplostomum sp. (Trematoda, Diplostomidae) y Lysapsus limellus Cope, 1862 (Anura, Pseudidae) en una poblacion local del nordeste argentino. Facena 1999; 15: 39-46.

International Union for Conservation of Nature - IUCN. Conservation international and natureserve: global amphibian assessment [online]. Cambridge: IUCN; 2015 [cited 2016 July 3]. Available from: www. globalamphibians.org

Ives AR, May RM. Competition within and between species in a patchy environment: relations between microscopic and macroscopic models. $J$ Theor Biol 1985; 115(1): 65-92. PMid:4046616. http://dx.doi.org/10.1016/ S0022-5193(85)80007-2.

Kennedy CR. Ecology of the acanthocephala. New York: Cambridge University; 2006.

Lent H, Freitas JFT, Proença MC. Alguns helmintos de batráquios colecionados no Paraguai. Mem Inst Oswaldo Cruz 1946; 44(1): 195-214. http://dx.doi.org/10.1590/S0074-02761946000100007.
Lomnicki A. Population ecology of individuals. Monogr Popul Biol 1988; 25: 1-216. PMid:3362150.

Madelaire CB. Relação sazonal entre reprodução, imunidade e ocorrência de endoparasitas em anfíbios anuros da Caatinga [Dissertação]. São Paulo: Instituto de Biociências, Universidade de São Paulo; 2012.

Olsen OW. Animal parasites: their life cycles and ecology. 7 th ed. Baltimore: University Park Press; 1986.

Poulin R. Phylogeny, ecology, and the richness of parasite communities in vertebrates. Ecol Monogr 1995; 65(3): 283-302. http://dx.doi. org/10.2307/2937061.

Poulin R. The functional importance of parasites in animal communities: many roles at many levels? Int J Parasitol 1999; 29(6): 903-914. PMid:10480727. http://dx.doi.org/10.1016/S0020-7519(99)00045-4.

Poulin R. Relative infection levels and taxonomic distances among the host species used by a parasite: insights into parasite specialization. Parasitology 2005; 130(1): 109-115. PMid:15700762. http://dx.doi. org/10.1017/S0031182004006304.

Poulin R, Krasnov BR. Similarity and variability of parasite assemblages across geographical space. In: Morand S, Krasnov BR. The biogeography of host-parasite interactions. New York: Oxford University; 2010. p. 115-128.

Rodrigues HO, Rodrigues SS, Faria Z. Contribution to the knowledge of the helminthological fauna of vertebrates of Maricá, Rio de Janeiro state, Brazil. Mem Inst Oswaldo Cruz 1990; 85(1): 115-116. http://dx.doi. org/10.1590/S0074-02761990000100020.

Rodrigues HO. Contribuiçấo ao estudo da fauna helmintológica de vertebrados de Nova Iguaçu, RJ. Atas Soc Biol Rio de 1986; 26: 27-28.

Segalla MV, Caramaschi U, Cruz CAG, Garcia PCA, Grant T, Haddad CFB, et al. Brazilian amphibians: list of species. Soc Bras Herpetol [online]. 2014 [cited 2016 July 7]. Available from: http://www.sbherpetologia.org. br/images/LISTAS/Lista_Anfibios2016.pdf

Smales LR. Acanthocephala in amphibians (Anura) and reptiles (Squamata) from Brazil and Paraguay with description of a new species.J Parasitol 2007; 93(2): 392-398. PMid:17539424. http://dx.doi.org/10.1645/ GE-937R.1.

Sousa WP, Grosholz ED. The influence of habitat structure on the transmission of parasites. In: Bell S, McCoy ED, Mushinsky HR. Habitat structure: the physical arrangement of objects in space. London: Springer; 1991. p. 300-324.

Vicente JJ, Rodrigues HO, Gomes DC, Pinto RM. Nematóides do Brasil 2a parte: nematóides de anfíbios. Rev Bras Zool 1990; 7(4): 549-626. http://dx.doi.org/10.1590/S0101-81751990000400015.

Walton AC. The Nematoda as parasites of Amphibia II. J Parasitol 1935; 21(1): 27-50. http://dx.doi.org/10.2307/3271792. 